American Journal of Animal and Veterinary Sciences 6 (2): 77-79, 2011

ISSN 1557-4555

(C) 2011 G. Yagoob et al., This open access article is distributed under a Creative Commons Attribution

(CC-BY) 3.0 license

\title{
Effect of Triclabendazole and Levamisole on Experimental Hydatic Cyst in Rat
}

\author{
${ }^{1}$ Garedaghi Yagoob, ${ }^{2}$ Khayatnouri Mirhadi, \\ ${ }^{3}$ Sadeghi Peyman and ${ }^{4}$ Safarmashaei Saeid \\ ${ }^{1}$ Department of Pathobiology, \\ ${ }^{2}$ Department of Pharmacology, \\ ${ }^{3}$ Post Graduated Student of Veterinary Medicine, \\ ${ }^{4}$ Young Researchers Club, \\ Tabriz Branch, Islamic Azad University, Tabriz, Iran
}

\begin{abstract}
Problem statement: Hydatidosis has dispersed worldly and is one of the common dangerous diseases between human and animals and is found abundantly in areas that human, dogs and herbivorous are in close relationship. Approach: In this study, firstly, 32 rats were divided into two groups of control and case and 2000 protoscolices were injected into peritoneal hole. After two months, rats of case group were feed by drinkable $5 \mathrm{~mL}$ Triclabendazole $+3.41 \mathrm{~mL}$ Levamisole for 60 days. Then after 6 months of contamination period, rats of control group and case group killed by anesthetic drug then necropsy and guts inspection of hydatid cyst was implemented. Results: The results show that in livers of control group there are 2 cysts, in kidneys 9 cysts and in lungs 87 cases. Average of contamination in this group to hydatid cyst was 32.6 but in case group there were in liver on cyst, in kidneys 5 cysts and in lungs 63 cysts. Average of guts contamination to hydatid cyst in case group was 23. Conclusion: Analyzing results in case and control groups shows that Triclabendazole + Levamisole drugs effect was $30 \%$ that this amount is not sufficient for hydatid cyst treatment.
\end{abstract}

Key words: Hydatid cyst, hydatic fluid, hydatic sand, flatworm echinococcus, cosmopolitan distribution, hydatid disease, peritoneal hole, occupying lesions, antihelminthic chemotherapy, latex agglutination

\section{INTRODUCTION}

Species under genus Echinococcus are small tapeworms of carnivores with larval (metacestode) stages known as hydatid proliferating asexually in various mammals including humans (Xiao et al., 2005; 2006). Hydatid cyst has a worldwide distribution and has been recognized since ancient times (Gulam et al., 2002). Human hydatidosis is a parasitic infection of the liver and other organs caused by the flatworm Echinococcus, most commonly E. granulosus which is a $5 \mathrm{~mm}$ long hermaphroditic tapeworm that has dog, foxes or coyotes as the definitive host and sheep, swine, cattle and zebra as the intermediate host. Hydatidosis is a cyclozoonotic infection of cosmopolitan distribution (Morris and Richards, 1992; Gossios et al., 1997). It is one of the main forms of parasitic disease in farm animals caused by the larval stage of Echinococcus tape worms which utilize canines as definitive host and various herbivores or rodent as intermediate host. These cysts are characterized by cystic space occupying lesions in the liver, the lungs and rarely in other parts of the body (Dhaliwal and Kalkat, 1997; Halilolu et al., 1997; Topcu et al., 2000; Ghaly, 2009). Therefore the aim of present study was to determine the effect of Triclabendazole on experimental hydatic cyst in rat.

\section{MATERIALS AND METHODS}

In this study, firstly, 32 rats were divided into two groups of control and case and 2000 protoscolices were injected into peritoneal hole. After two months, rats of case group were feed by drinkable $5 \mathrm{~mL}$ Triclabendazole $+3.41 \mathrm{~mL}$ Levamisole for 60 days. Then after 6 months of contamination period, rats of control group and case group killed by anesthetic drug

Corresponding Author: Garedaghi Yagoob, Department of Pathobiology, Tabriz Branch, Islamic Azad University, Tabriz, Iran Tel: 00989143110499 
then autopsy and guts inspection of hydatid cyst was implemented. Then number of hydatic cyst in internal organs especially liver, lungs and kidneys of rats were enumerated and also hydatic fluid aspirated and by light microscope for inspection of hydatic sand was studied.

\section{RESULTS}

All results of present study in following tables and figures have been shown. Table 1 and 2 shows the number of hydatic cyst in rats of control and case groups respectively. Figure 1 and 2 shows hydatic cysts in rats.

Table 1: Number of hydatic cyst in control group

\begin{tabular}{lcll}
\hline $\begin{array}{l}\text { Infected } \\
\text { organ }\end{array}$ & $\begin{array}{l}\text { No of } \\
\text { hydatic cyst }\end{array}$ & $\begin{array}{l}\text { Color of } \\
\text { hydatic cyst }\end{array}$ & $\begin{array}{l}\text { Diameter of } \\
\text { hydatic cyst }\end{array}$ \\
\hline $\begin{array}{l}\text { Liver } \\
\text { Kidney }\end{array}$ & 2.0 & White & $2-5 \mathrm{~mm}$ \\
$\begin{array}{l}\text { Lung } \\
\text { Average of infestation } \\
\text { to hydatic cyst }\end{array}$ & 8.0 & White & $5-6 \mathrm{~mm}$ \\
\hline
\end{tabular}

Table 2: Number of hydatic cyst in case group

\begin{tabular}{llll}
\hline $\begin{array}{l}\text { Infected } \\
\text { organ }\end{array}$ & $\begin{array}{l}\text { No of } \\
\text { hydatic cyst }\end{array}$ & $\begin{array}{l}\text { Color of } \\
\text { hydatic cyst }\end{array}$ & $\begin{array}{l}\text { Diameter of } \\
\text { Hydatic cyst }\end{array}$ \\
\hline Liver & 1 & White & $2-4 \mathrm{~mm}$ \\
Kidney & 5 & White & $4-5 \mathrm{~mm}$ \\
Lung & 63 & White & $2-6 \mathrm{~mm}$ \\
$\begin{array}{l}\text { Average of infestation } \\
\text { to hydatic cyst }\end{array}$ & 23 & - & - \\
\hline
\end{tabular}

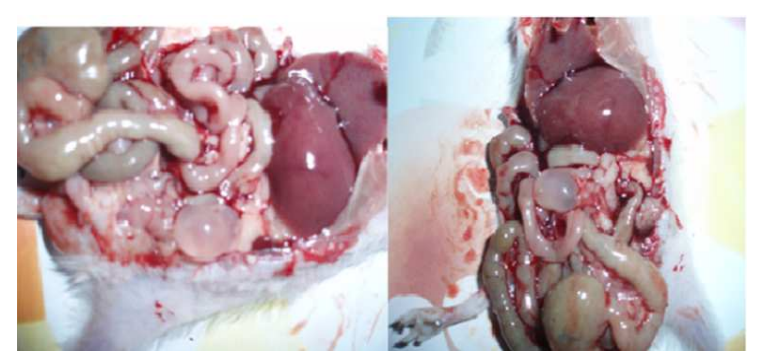

Fig. 1: Hydatic cyst into internal organs of infected rats

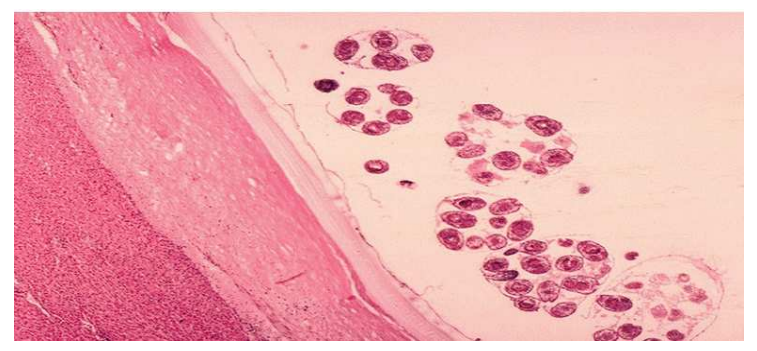

Fig. 2: Hydatic sand and protoscolex of it

\section{DISCUSSION}

Hydatid disease is known since the time of Hippocrates. Although the liver is the most common site of infection in adults, the most common site of infection in children is the lung (Topcu et al., 2000; Halilolu et al., 1997; Dhaliwal and Kalkat, 1997). Hydatid disease is seen endemically among sheep raising communities. The disease still continues to be a serious problem in countries like Australia, New Zealand, Middle East, Africa, India, South America, Turkey and Southern Europe (Arora et al., 2006). Various soft tissue sites involved by hydatid cysts and reported in literature include those of muscles and subcutaneous tissue (neck, chest, axilla, abdomen, thigh and palm) (Dirican et al., 2008; Bedioui et al., 2007).

In humans Routine laboratory tests can only reveal eosinophilia. A number of serological tests can be done for screening, diagnosis and follow up for recurrence of hydatid disease. Highly sensitive tests include indirect haemagglutination and Latex agglutination test. Confirmation of diagnosis can be done by highly specific tests including immunoelectrophoresis, double diffusion test and ELISA and radioallergosorbent test (Xiao et al., 2006). Radiological imaging including USG, CT and MRI are excellent imaging modalities for hydatid cysts, which can delineate exact site as well as identify the daughter cysts and hydatid sand which are specific to echinococcal infestation. MRI can also show a typical distinctive feature of cyst within cyst in case of the multicystic hydatid cyst (Chevalier et al., 1994).

So fare some study on this subject has been done; in one study by Horton et al. (1999) study on Chemotherapy of Echinononnus infection in Rat with albendazole was done and efficacy rate of this drug $46 \%$ reported. In other study efficacy rate of Triclabendazole on treatment of hydatic cyst 39\% reported. In study on Chemtherapy of Echinococcus infection in Rat with Triclabendazol-Levamisole effect of these drugs on treatment of lung hydatic cyst $37 \%$, liver hydatic cyst $41 \%$ and renal hydatic cyst $28 \%$ were determinate. In study by Polat et al. (2009) on effect of albendazole and povidone iodine For Hydatid cysts protoscolices, in vitro and- vivo, the efficacy rate of albendazole $95 \%$ reported. Surgery remains the treatment of choice for hydatid cyst. Antihelminthic chemotherapy alone may be effective in $30-40 \%$ of patients. It is most effective in alveolar hydatid, less so for liver infections and essentially ineffective for the diseases of the bone, brain, eye and other sites. Hydatid cyst is best treated by complete excision of the cyst (Arora et al., 2006). 


\section{CONCLUSION}

Result of present study indicated that administration of Triclabendazole-Levamisole for hydatic cyst treatments is not sufficient in rats.

\section{REFERENCES}

Arora, V., I.S. Nijjar, K.S. Gill and G. Singh, 2006. Case report: Primary hydatid cyst of muscle-a rare site. Indian .J Radiol. Imag., 16: 239-241. DOI: 10.4103/0971-3026.29100

Bedioui, H., A. Makni and K. Nouira, A. Mekni_and A. Daghfous et al., 2007. Subcutaneous hydatid cyst. Case report of an exceptional location. Med. Trop (Mars), 67: 181-182. PMID: 17691440

Chevalier, X., A. Rhamouni, S. Bretagne, J. Martigny and B. Larget Piet, 1994. Hydatid cyst of the subcutaneous tissues without other involvement: MR imaging features. AJM Am. J. Roentgenol, 163: 645-646. PMID: 8079861

Dhaliwal, R.S. and M.S. Kalkat, 1997. One stage surgical procedure for bilateral lung and liver hydatid cysts. Ann. Thorac Surg, 64: 338-41. PMID: 9262571

Dirican, A., B. Unal, C. Kayaalp and V. Kirimlioglu, 2008. Subcutaneous hydatid cyst occurring in palm and thigh; two case reports. J. Med. Case Reports, 2: 273. DOI: $10.1186 / 1752-1947-2-273$

Ghaly, A.E., 2009. The black cutworm as a potential human food. Am. J. Biochem. Biotechnol., 5: 210220. DOI: 10.3844/ajbbsp.2009.210.220

Gossios, K.Y., D.S. Kontoyiannis, M. Dascalogianaki and N.C. Gourt Soyiannis, 1997. Uncommon location of hydatid disease. Eu. J. Radiol, 7: 130308. PMID: 18626530

Gulam, N.L., A.B. Mohd, A. Noor, B. Adil and A.G. Showkat, 2002. Single stage bilateral minimally invasive-approach for pulmonary hydatid diseases an alternative technique. J. Thorac. Cardiovasc Surg., 124: 1021-1024. DOI: 10.1067/mtc.2002. 122315
Halilolu, M., I. Saatci, O. Akhan, M. Ozmen and A. Besim, 1997. Spectrum of imaging findings in pediatrichydatid disease. AJR Am. J. Roentgenol, 169: 1627-1631. PMID: 9393178

Horton, R.J., 1999. Chemotherapy of Echinononnus infection in man with albendazole. Trans. R Soc. Trop. Med. Hug., 83: 98-103. DOI: 10.1016/00359203(89)90724-4

Morris, D.L. and K.S. Richards, 1992. Text Book of Hydatid Diseases; Current Medical and Surgical Management. 1st Edn., Butterworth, Heinamann, London, ISBN: 9780750613798, pp: 25-30.

Polat, E., M. Aslan, H. Cakan, S. Saribas and T. Ipek et al., 2009. The effect of albenda zole and povidone iodine for hydatid cysts protoscoleces, in-vitro and vivo. Afr. J. Microbiol. Res., 3: 743-746. ISSN: 1996-0808

Topcu, S., C. Kurul I, I. Tastepe, D. Bozkurt and E. Gulhan et al., 2000. Surgical treatment of pulmonary hydtid cysts in children. J. Thorac. Cardiovasc. Surg., 120: 1097-10101. http://jtcs.ctsnetjournals.org/cgi/content/full/120/6/ 1097

Xiao, N., J. Qiu, M. Nakao, T. LI and W. Yang et al., 2005. Echinococcus shiquicus n. sp., a taeniid cestode from Tibetan fox and plateau pika in China. Int. J. Parasitol., 35: 693-701. PMID: 15862582

Xiao, N., J. Qiu, M. Nakao, T. Li and W. Yang et al., 2006. Echinococcus shiquicus, a new species from the Qinghai-Tibet plateau region of China: Discovery and epidemiological implications. Parasitol. Int., 55: 233-236.PMID: 16337180 